\title{
Ferments and the AIDS virus: interspecies counter- conduct in the history of AIDS
}

\author{
Justin Abraham Linds
}

Correspondence to Justin Abraham Linds, Social and Cultural Analysis, New York University, New York, NY 10003, USA; jal909@nyu.edu

Accepted 12 June 2019 Published Online First 13 August 2019

\section{ABSTRACT}

In the first three decades after AIDS started infecting people in the USA and Canada, before, during and after the emergence of anti-retroviral therapies, numerous "alternative and holistic treatments" for AIDS were debated, tested, circulated, written about and taught. This paper, taking a narrow focus, examines documents that reveal how some people with AIDS developed a logic of care predicated on intimate interactions with microscopic lifeforms - the AIDS virus and the bacteria involved in fermentation, in particular. Focusing on the writings of Jon Greenberg and Sandor Katz, two former members of ACT UP/NY, I show that the men did not just dissent from management by biomedical authority but found new authority about how to care for themselves as people with AIDS from their interactions with non-human microscopic life. The practices and writings of both men demonstrate that Foucault's theory of counter-conduct exists in the history of AIDS as an interspecies process in which microscopic existents lead humans. From Katz and Greenberg, I argue there is an interspecies dimension to counter-conduct that exists as a frame for understanding people who find in non-human life a guide towards unconventional forms of care, revised forms of human behaviour and philosophies for persisting with illness.

\section{THE ALTERNATIVE AND HOLISTIC TREATMENT COMMITTEE}

In the first three decades after AIDS started infecting people in the USA and Canada, before, during and after the emergence of anti-retroviral therapies, numerous "alternative and holistic treatments" for AIDS were debated, tested, circulated, written about and taught. Within numerous folders in the New York Public Library's collection of ACT UP (AIDS Coalition to Unleash Power) New York Records, there are descriptions from the late 1980s and early 1990s about the curative potential of treatments involving bitter melon, intravenous garlic extract, Chinese herbal treatments, "bone marrow aspiration", acupuncture, hydrogen peroxide, "living foods", peptide T, marijuana, macrobiotics, mushrooms, massage, wheat grass, algae, hypericin, spiritualism, Santeria and much more.

The ACT UP documents detailing the science of alternative treatments for AIDS imbue a wide range of material substances with curative potential and indicate numerous parallel and collaborative battles by queer communities and communities of colour to gain recognition and support for their diverse doctoring practices. Different forms of Chinese Medicine were adopted by and advocated for by members of ACT UP/NY's Alternative and Holistic
Treatment Committee (AHTC) for their "immunoregulation" properties, and there is evidence that the legal accreditation of acupuncture in New York State, authorised by the New York State Senate in May 1990, shares a history with AHTC, which mobilised members to write letters and agitate public figures as part of a broad coalition of advocates for Chinese Medicine. ${ }^{1}$ In the late 1980s and early 1990s, people organising teach-ins and meetings to discuss alternative treatments for HIV/AIDS invited speakers on Santeria and the spiritualism of the "hispanic community" to their gatherings so as to better understand the spiritualism informing the care practices of some people with AIDS (PWAs). ${ }^{2}$ The documents lament the slowness and the cruelness of clinical trials and one even makes reference to Michael (sic) Foucault's The Birth of the Clinic, "But to look in order to know, to show in order to teach, is not this a tacit form of violence, all the more abusive for its silence upon a sick body that demands to be comforted, not displayed?"3

This paper, taking a narrow focus, examines specific documents that reveal how PWAs throughout the AIDS epidemic attributed curative potential to nonhuman lifeforms-viruses and bacteria, mostly-while developing a logic of care more intimate with non-human life than trustful of human-only scientific procedures. In what follows below, I describe what I call the interspecies counterconduct of these PWAs: their intentional collaboration with and conduction by non-human forms of existence towards an interspeciated conception of betterment.

The work of ACT UP subcommittees and affiliate groups like Treatment Alternatives, the Treatment Alternatives Program and the AHTC has been under-described by historians of medicine, in general, and scholars interested in the American AIDS epidemic, specifically. ${ }^{4}$ While the ACT UP protests of the American Medical Association are well known, less known are the efforts of ACT UP organisers within AHTC to stop the National Institute of Allergy and Infectious Diseases from spending tens of thousands of dollars on private research firms working to compile and profit from databases evaluating "Unproven Remedies for AIDS". 5 Excellent and now classic work has been done on the broad and intersecting forms of expertise about AIDS that developed as "activist-experts" became highly knowledgeable about the disease, its causes and its possible treatments. However, that history of activist-expertise has, in Steven Epstein's words, "analyze[d] tendencies toward professionalization within social movements that engage with expert knowledge". ${ }^{6}$ This paper, then, pursues 
treatment practices and logics that Epstein confines to the subordinate clause: "Although some community spokespeople endorse New Age therapeutic methods ranging from 'creative visualizations' to healing crystals, most activists accept that a solution to the deadly AIDS epidemic will arrive via some variety of scientific process...". This paper focuses on expertise, but expertise that is developed in collaboration with existents such as viruses and bacteria that are generally derided as pathogenic. ${ }^{8}$ It navigates the contours of authoritative knowledge about AIDS, but authoritative knowledge about AIDS that is articulated by PWAs who define authority in relation to the degree of intimate attention that one gives to the non-human life inside them. In short, it describes interspecies counter-conduct.

\section{INTERSPECIES COUNTER-CONDUCT}

"Interspecies" and "counter-conduct" are two heuristics for understanding human social relations, and bringing them together in this paper helps me more accurately describe events from the history of AIDS in America that have not been engaged elsewhere. Multispecies medicine is too capacious a term to accurately describe the efforts taken by PWAs in the early years of the AIDS epidemic who learnt from viruses and bacteria a way of persisting in a state of illness. Multispecies medicine functions broadly as it directs attention to the numerous ways the health of one being - usually humans-is mixed up in the life, death, use or employment of many other beings of different species. "Interspecies" stays with inter-relations between distinct forms of life but "probes the limits of this distinction", questioning species boundaries and the social and affective processes by which they are breached. "Interspecies" does not take up the wild-goose chase of non-human agency, taking it for granted that agency is a contentious historical and political category and that even something 'without' agency can have relations and meaningful social and political impacts. ${ }^{10}$

Heather Paxson and Stefan Helmreich give the label "PostPasteurian" to relations between microbes and humans in which humans do not dream of controlling all microbes. "Postpasteurian" recognises risk, guards against infection and "moves beyond Pasteurianism in recruiting 'good' microbes as friends and allies" in various interspecies efforts. ${ }^{11}$ Recruiting microbes and letting them flourish means regarding them as agents who perform as they will, harmfully or not. The medical scenario being considered in this special issue of Medical Humanities is named 'being well together', but this paper complicates the scene by describing an interspecies interaction that casts cautious light on what it means to be 'well' with microscopic life. Microbes and viruses frequently do well when humans do not. I append "interspecies" to "counter-conduct", then, because the micro-history of AIDS I make below describes a form of conduct related to healing that does not conform to many of the expectations of medicine. Below you will find examples of interspecies conduct of care but not care devoted necessarily to extending human life. ${ }^{12}$

"Counter conduct" describes the conduct of humans who dissent from one form of governance by taking a new leader, shepherd or conducteur. First described by Michel Foucault in a lecture on 1 March 1978, which would go on to be included in Security, Territory, Population, counter-conduct does not describe escape from the power that manages populations, for counterconduct involves replacing one conducting power with another. Counter-conduct has been usefully taken up in the medical humanities, especially by scholars writing histories of alternative health movements. ${ }^{13}$ It is not surprising why: Foucault names "medical knowledge, institutions, and practices" as an example of a force of governmentality that shepherd humans, and he gives as an example of dissent from medical governance "the refusal of certain medication and certain preventative measures like vaccination and the refusal of a certain type of medical rationality". ${ }^{14}$ Consequently, and because counter-conduct describes active but also ideological dissent from medical governance, the term helpfully describes the twin efforts of certain alternative health movements to change how they experience health but also how they think about health. It would not be difficult or unrevealing to think through the AHTC or other alternative health movements from the early years of the AIDS epidemic via the concept of counter-conduct. This paper, however, modifies counter-conduct by thinking through its interspecies potential in order to better understand the AIDS activists who chose a way forward in close collaboration with nearly invisible, microscopic forms of existence.

Jon Greenberg and Sandor Katz, the two men with AIDS whose writing is at the centre of this paper, found in minute non-human lifeforms allies and teachers instructing dissent from certain forms of medical rationality. Doing so, they let themselves be conducted by a form of non-human life that paid them no regard. This proved to be a dangerous proposition, but Foucault's formation of counter-conduct is dangerous. Katz and Greenberg realised what they were doing was risky, yet they let themselves be conducted towards risk nonetheless. Just because something is risky does not mean it is foolish or stupid or not worth analysing. ${ }^{15}$ This paper is not a test of the medical establishment's or the public's faith in idiosyncratic, interspecies practices of care. Rather, it reports what some humans found attributing pedagogical authority first to AIDS and then to other microscopic existents in order to understand interspecies narratives related to health that are risky and perhaps unadvisable from an allopathic standpoint but which nonetheless take powerful hold in the imagination and the lives of people living with disease and so should take hold in the work of medical practitioners and scholars writing histories of science and medicine.

\section{JON GREENBERG: "A CONDUIT BETWEEN TWO WORLDS"}

Jon Greenberg was the "national/international contact person for general information" for Treatment Alternatives, founded in May 1991, and a member of the Alternative and Holistic Treatment Subcommittee, both committees within ACT UP/ NY. His activism centred him in New York City, although, for the purposes of teaching and researching alternative treatments for AIDS, he travelled across the USA and Europe. Greenberg is perhaps most famous for his oft-cited aphorism, "I don't want an angry political funeral. I just want you to burn me in the street and eat my flesh"; indeed, when he died in July 1993, his casket was carried through the Lower East Side to Tompkins Square Park as a form of public anger and public mourning. ${ }^{16}$

Greenberg was a protean figure, oscillating between and never settling on one way to respond to AIDS. He was devoted to "the creation and implementation of controlled clinical trials of commonly used 'alternative' and non-pharmaceutically based AIDS treatments". ${ }^{17}$ Yet, he also acknowledged that alternative treatments were fickle things and sometimes "there may be no research model for [them]". ${ }^{18}$ In a document from September 1991, Greenberg defines the mission of the working group Treatment Alternatives and elaborates his understanding of what an alternative treatment is. "ALTERNATIVE refers to treatments which have not been developed in a pharmaceutical laboratory and are not currently included in the established 
research system". ${ }^{19}$ An alternative treatment might be a natural substance. It might be a "mixed, not purified substance". It may be considered a food product or a "technique, not an agent at all". ${ }^{20}$ Astutely, Greenberg writes that an alternative therapy in one country may not be alternative in another. The goal of Treatment Alternatives, he wrote, is to move alternative treatments into the "accepted standard of care". ${ }^{21}$ This mission meant working to push ignored forms of care through the clinical trial system, with the keyword being push. The subcommittee was explicitly committed to action, "not causes or theories". ${ }^{22}$ Members of Treatment Alternatives did everything from writing fact sheets, to collecting scientific abstracts, to putting pressure on researchers, but Treatment Alternatives was not meant to be a discussion group "talking about theory". ${ }^{23}$

That being said, Greenberg was not incapable of entering the realm of the theoretical and the metaphysical. A fundamental aspect of his work at Treatment Alternatives involved bridging the worlds of scientific researchers and alternative and holistic practitioners. Greenberg saw that these two groups found it hard to understand one another and so imagined members of Treatment Alternatives "serv[ing] as a conduit between the two worlds so that from their combined areas of expertise can come useful treatments and information". ${ }^{24}$ With that aim in mind, in January 1992 Greenberg spent 14 days travelling the West Coast of the USA, meeting with and bringing together the ideas of four AIDS researchers, eight alternative treatment advocates and innumerable AIDS activists. In a 14-page report on the trip, Greenberg describes his efforts transforming one researcher's "line of reasoning" to make it clear to himself and others. In the report, a practitioner of Chinese Medicine working with herbs at the Institute for Traditional Medicine in Portland, Oregon wants to define the efficacy and toxicity of herbs via the principles of traditional Chinese Medicine. Greenberg wants those criteria defined and made relevant to other health paradigms, and when he does not get definitions, he becomes angry, close to screaming. ${ }^{25}$ Being a conduit between worlds is not easy or unemotional work.

Several months after his West Coast trip, in the year before he died, Greenberg stood on a stage at the more sombre than usual Eighth International Conference on AIDS in Amsterdam and told the audience that he had "finally come to the realization that the power to heal comes from within, not from without". ${ }^{26}$ In a line of theory moving into the spiritual, Greenberg elaborated "that the source of [his healing] power is a larger universal spirit which only [he] can tap into for [himself]". ${ }^{27}$ In that same speech, Greenberg went on:

I believe that PWAs [People with AIDS] have an understanding of this condition and how to best live with it that no doctor who is not a PWA can begin to comprehend simply because he or she is not living with it inside his or her body; that by listening to my body I am also listening to this thing called AIDS and that consequently I understand it in a way that no person not living with AIDS can... ${ }^{28}$

By listening to a cosmic spirit, his body and AIDS itselfnot the discourses of medical experts or alternative health practitioners-Greenberg learnt not a new treatment method but a new paradigm of care. In this speech, knowledge about AIDS is not derived from double-blinds; comprehension is an embodied experience of living in close proximity to viral life. From non-human forms of existence but also feelings and sensations, Greenberg is "learning the most wonderful lessons of his life through direct contact with pain and confrontation with death". ${ }^{29}$ In his metaphysics of care, AIDS is a teacher of lessons-“not a punishment but a gift". ${ }^{30}$ Clinical trials are still important to Greenberg but because they "give [him] direct contact with the treatment option and [he doesn't] have to rely upon other people's stories to make [his] decisions". ${ }^{31}$ Clinical trials lead Greenberg to forms of self-care for the same reason AIDS and spirits and pain lead Greenberg to self-care: because they provide him with information that he can interpret alone. Thus, in one archival moment, Greenberg is excitedly describing meetings with numerous AIDS researchers and treatment practitioners; in another, he is a student of AIDS, the teacher that instructs dissent from medical expertise if it lacks the disease's 'voice', the lessons of the pathogenic life form. The more-thanhuman element of Greenberg's thinking lies in his two-step recommendation in which (1) PWAs "empower themselves with knowledge and information" and (2) PWAs acknowledge that the disease pathogens themselves have forms of knowledge that they can listen to if they "reject other doctors". ${ }^{32}$

Greenberg's role as articulated in the founding documents of Treatment Alternatives was to bridge medical knowledge systems: Western and non-pharmaceutical and alternative, scientific and holistic. A year later, however, he positioned himself as a conduit of another kind, between AIDS and his human audience. Greenberg spoke as a conduit between human and non-human, between a system of logic honouring scientific principles striving for certainty and a system of care that emerges from attention to the lessons of microscopic non-human life. He advocated for a form of self-empowerment in knowledge in which some of that knowledge came from non-human sources, be they numinous, corporeal or viral.

The timing of Greenberg's 1992 speech is significant because it occurred in the same period that numerous ACT UP chapters across the USA experienced organisational splits. The most well-known breakage was between those who prioritised getting "drugs into bodies" and those who articulated a broader critique of the US healthcare system and "the racist, sexist, and homophobic dimensions of biomedicine". ${ }^{33}$ Additionally, a secondary split-one that partially describes Greenberg's situation-tore between those members of ACT UP who desired a professionalisation of treatment activism and more emphasis on Western medicine and those who desired more investigation in alternative treatments and non-Western conceptions of healing. ${ }^{34}$ Still, how and why Greenberg found "the power to heal" from "listening to this thing called AIDS" is more complicated than a simple rejection of pharmaceutical medicine. Greenberg might have turned from trusting the authority of clinicians and researchers to a devout practice of Vipasana meditation, or an artistic life, or a rural lifestyle as others living with AIDS did. How can we better understand Greenberg giving intimate attention to the virus living in his body? And what does microscopic non-human life teach about care?

\section{INTERSPECIES FOUCAULT}

In his 1 March 1978 lecture at the Collège de France, the French philosopher Michel Foucault elaborated on how populations, what Foucault calls the pastorate, are "deployed to a great extent through medical knowledge, institutions, and practices". 35 The pastorate is produced, according to Foucault, by a unique form of power called pastoral power that takes behaviour as its target in the conducting of populations. ${ }^{36}$ Medicine is constitutive of pastoral power in the language of care: pastoral power is "a power of care... It looks after the flock, it looks after the individuals of the flock, it sees to it that the sheep do not suffer, it goes in search of those that have strayed off course, and it treats those 
that are injured". ${ }^{37}$ Somewhat disembodied, pastoral power resides in the ambiguous form of the "shepherd... someone who feeds the flock first by leading it to good pastures". ${ }^{38}$

Foucault describes the specificities of pastoral power-and its secular form, called governmentality-by describing the "equally specific" movements of resistance and insubordination that appear in response. Foucault calls these responses "revolts of conduct... leaving the word 'conduct' in all its ambiguity". ${ }^{39}$ Importantly, he elaborates that these revolts have as their objective "wanting to be conducted differently, by other leaders (conducteurs), and other shepherds, towards other objectives and forms of salvation, and through other procedures and methods". ${ }^{40}$ After a lengthy discussion of the right and wrong language for describing this behaviour, he eventually names it counter-conduct and enumerates some examples, the third of which is the refusal of certain medications and preventative measures such as vaccines. ${ }^{41}$ Wanting to be conducted by new leaders towards deliverance from harm, convinced there are other methods for self-preservation against ruin, humans embrace "medical dissent... the refusal of a certain type of medical rationality". ${ }^{42}$ Medicine is a component of pastoral power, and alternative practices of care may be part of the subversion of pastoral power. The human multiplicity has its movements cared for, shepherded, by pastoral power; then, the human multiplicity or the individual finds another form of care lead by another conducteur and follows it. Counter-conduct is not liberation from being conducted; it is conduction by something else.

As Foucault discusses counter-conduct as the desire to be conducted differently_- "by other leaders (conducteurs), and other shepherds..."-he implies a question that remains open: who are these other leaders, these other conducteurs? That Foucault is ambiguous about the word 'conduct' is important to my thesis that counter-conduct exists in the history of AIDS as an interspecies process of conduction of humans by microscopic existents. ${ }^{43}$ Foucault does not name non-human life as a possible shepherd, but later in Security, Territory, Population he will describe counter-conduct as a composite form made up of dimensions of behaviour found in "delinquents, mad people, and patients" and so increase the possibility for identifying different shepherds in the "immense family of what could be called counter-conducts". ${ }^{44}$ Then, in his 1982 elaboration on counter-conduct from "The Subject and Power", Foucault continues to expand what might count as a shepherd of pastoral power, naming the family, the police, medicine, philanthropists and stating in general that fine-tuned analyses of power and counter-conduct require acknowledging that "the officials of pastoral power [have] increased" ${ }^{45}$ In this line, I suggest that we increase our consideration of the possible officials of pastoral power so that non-human lifeforms are taken seriously as figures capable of conducting the behaviour of humans. I am suggesting we recognise (in this history of AIDS, at least) forms of counterconduct in which humans take a non-human lifeforms as their conducteur: interspecies counter-conduct.

It is nothing new to consider the animal lying couched in the metaphoric language of Foucault's constructions of pastoral power, governmentality and counter-conduct. In her article, "Tense Animals: on Other Species of Pastoral Power", Nicole Shukin literalises Foucault in order to consider the "sheep" in Foucault's construction of pastoral power and speculate about the implications of conceiving of pastoral power as a "discourse of species". ${ }^{46}$ Shukin de-centres the human apparently at the heart of Foucault's construction, making room for other animals to be considered as subjects of pastoral power. In doing so, she seeks to open up what Foucault forecloses: “... how contingent governmentality may be on the production and ordering of 'species' as a play of similarity and difference". ${ }^{47}$ Shukin has paved considered theoretical ground for asking, "what if the species of the pastoral subject isn't taken as a given?"48 I modify this question, however, by asking, what if the species of the pastor isn't taken as a given? Non-human lifeforms can lead humans to dissent from medical paradigms. When the non-human shepherd is imbued with the agency of action by its human sheep, it can lead a form of conduct. Indeed, "this thing called AIDS" 49 conducted Jon Greenberg when he allowed it to teach him "that sometimes the only way to begin to listen to one's own body and tap the knowledge within is to stop listening to everyone else outside" and start listening to the forms of liveliness inside. ${ }^{50}$

\section{SANDOR ELLIX KATZ: "WHAT IF HIV IS NOT THE WHOLE STORY?"}

Sandor Ellix Katz is the author of Wild Fermentation (2003), The Revolution Will not be Microwaved (2006) and The Art of Fermentation (2013). Wild and Art are fermentation cookbooks, but they are also rich in memoir, cultural theory, poetry, history, cultural revivalism, manifesto, illness writing and more. Michael Pollan has said of Art, it "is a cookbook in the same way that Zen in the Art of Archery is a how-to about bows and arrows". 51 Today, Katz lives adjacent to a commune of queer "radical faeries" in the mountains of Tennessee, where he has lived for many years, and he tours the world giving workshops on fermentation. ${ }^{52}$

Katz's ${ }^{53}$ name appears in the archive of alternative and holistic treatments for AIDS at the New York Public Library at least once, sitting below Greenberg's in a poster recruiting volunteers for ACT UP's Treatment Alternatives Project. The two are most intimately paired, however, in the opening of Katz's first book, Wild Fermentation, which opens,

Dedicated to Jon Greenberg (1956-1993)

This beloved ACT UP comrade first articulated to me the idea of peaceful coexistence with microbes rather than warfare. I honor Jon and all our fellow skeptics, rebels, and iconoclasts who question prevailing wisdom and authority. Believe in the future and keep change fermenting. ${ }^{54}$

In the dedication, Katz lines up Jon Greenberg, coexistence with microbes and a critique of normative authority. In this close paratextual encounter, we can see both men invested in attributing authority to different but metonymic minute lifeforms as guides for rebellious, iconoclastic human conduct. Katz and Greenberg share an investment in interspecies counter-conduct, which began for both men when they found dissent from medical governance via conduction by microscopic non-human existents. In this section of the paper, I turn to Katz's published writing to follow the way he transposes interspecies counter-conduct from the AIDS virus to another microscopic conducteur and so makes interspecies counter-conduct available to a wider array of readers. Katz is antagonistic towards being medically managed as a PWA, but from his antagonism he articulates not just a rejection of modern medical thought, which would be one thing. Katz articulates philosophies and practices of care led by the bacteria that make the process of fermentation possible, which is another.

Katz believes he is caring for his weakened immune system by making fermented foods (and he may be), but from his close working with microscopic existence, Katz derives a theory of interspecies interaction and pedagogy with fermenting microbes who impart lessons about a form of interspeciated care. ${ }^{55}$ 
Coexistence with microbes in the form of fermentation involves submitting to the microscopic non-human's lessons, identifying with their transformation of the social order, and being open to their revision of scientific and medical concepts. Coexistence with microbes is not a disease intervention that could contain an outbreak, but it is still a disease intervention. Coexistence with microbes is not a highly technological response to a pathogen, yet it is innovative and complex. ${ }^{56}$

The therapeutic orientation Greenberg derived from viral life and spoke about onstage in Amsterdam is transposed in Katz's writing, altered into theories and behaviours that take another microscopic type as leader. Katz's fermentation practice begins because of his HIV diagnosis and his connexion to what he calls the "AIDS underground". But whereas fermenting food might have left Katz with just crocks full of tangy krauts and a conviction that he was nurturing his immune system with probiotic goodness, it went further and imparted in him a gospel of interspecies collaboration the he now shares with his readers. Fermenting food is for Katz a practice of counter-conduct in which various microscopic non-human existents lead. A familiar question bubbles to the surface: What social behaviour and practices of care did Katz adopt after giving intimate attention to the tiny non-human things living in and around his body?

ACT UP and HIV/AIDS both haunt the paratextual, instructional and narrative elements of Katz's books. In the author biography for Wild Fermentation it says, "a long-term HIV/AIDS survivor, Katz considers fermented foods to be an important part of his healing", and in the acknowledgements Katz writes that Wild gave his life focus and meaning at a time when he was in "the abyss" of AIDS. ${ }^{57}$ In the introduction, Katz tells his reader that fermented foods bolstered his ability to tolerate AIDS drugs and their well-known intestinal upset. ${ }^{58}$ In a similar vein, Katz's texts reveal a familiarity with ACT UP and what Katz calls the "early AIDS treatment underground movement". ${ }^{59}$ In Art, he cites a 1995 pamphlet that compiles dietary and lifestyle advice for living with AIDS called "How to Reverse Immune Dysfunction" in order to relay to his readers the healthful logic of liquid infusions, specifically "cultured cabbage "juice"”. ${ }^{60}$ Katz writes that he first heard about the nutrient-rich cabbage juice before he developed a specific interest in fermentation, and his timeline is similar with the fermented beverage kombucha, which he first tried in 1994, when a friend of his with AIDS started making and drinking it as a health practice. ${ }^{61}$

In his published books, Katz writes with Treatment Alternative's ethos of medical scepticism, recalling especially Greenberg's later virulence against not just medical practices but medical logics. Katz writes, "drugs are antithetical to everything I believe and the values I've devoted myself to". ${ }^{62}$ The thought of being medically managed is painful to him, but it is not just pharmaceutical therapies and their profit-motive that Katz is troubled by. The rationality of medical diagnosis, especially the medical diagnosis of AIDS, is suspect to Katz.

In The Revolution will not be Microwaved, Katz writes in a passage worth quoting at length:

I wasn't completely sold on the lone-assassin HIV theory. I believed, as I continue to believe, that the story of AIDS is more complex and multifactoral than a single rogue retrovirus. Some facts must account for the many anomalies, like the people who test positive for HIV but never develop AIDS, and others who develop AIDS symptoms but never test positive for HIV. What are these factors? Are they genetic? Behavioral? Environmental?... What other factors might explain individuals' widely varying disease progression?... The mainstream medical establishment, as well as the AIDS service providers for the most part, view questioning the conclusion that HIV is the cause of
AIDS as preposterous and in complete contradiction with reality. They suggest that because effective strategies for long-term treatment have been devised according to this model, it must be correct. My knee-jerk skeptic's question is, what if HIV is not the whole story? What if the varied symptoms we categorize as AIDS are triggered by other factors as yet undetermined? Knowledge is imperfect and evolving. ${ }^{63}$

In this passage from 2005, Katz rejects knowledge as it is "sold" to him, desires a plurality of causation, and regards all knowledge as incomplete. His most virtuosic moment of scepticism occurs when he argues that effective long-term HIV/AIDS treatments, based around a specific model of disease causation, do nothing more than meet a standard already agreed upon as good, not confirm the truth of the model of causation. Katz problematises the implied relationship between treatment and disease, between effect and cause. Just because you can diminish someone's symptoms, he argues, does not mean you understand their illness. It is a critique of medical truth and the label of efficacy that applies to treatments that are embraced even when those treatments are not universally effective. It is a critique of the way scientific norms have historically been adopted even when there are contradictions that undermine the breadth of applicability. ${ }^{64}$ In his writing, Katz espouses a dissidence against the performance of certainty embedded in certain forms of medicine. In the language of Foucault, Katz dissents from medical rationality in order to be conducted otherwise. What remains to be shown is that the form of conduct he pursues takes microscopic nonhuman life as its shepherd. As I will demonstrate below, Katz's books reveal his commitment to interspecies counter-conduct. Furthermore, Katz transforms that commitment into lessons for readers as he uses language to describe fermenting life as a teacher.

In what follows, I read Wild and Art simultaneously in order to highlight the pedagogical authority Katz gives microscopic life for directing human behaviour when making fermented foods and beyond. Andrew Hunt's Dictionary of Chemistry describes fermentation as such: "Fermentation converts sugars to alcohol (ethanol) and carbon dioxide. Fermentation is an example of anaerobic respiration. Fermentation is catalyzed by a group of enzymes from yeast referred to as zymase". ${ }^{65}$ Meanwhile, Katz describes the same process as "a health regimen, a gourmet art, a multicultural adventure, a form of activism, and a spiritual path... Fermentation is magical and mystical". ${ }^{66}$ Katz calls micro-organisms "our ancestors and our allies" and describes their role as teachers from the outset of his book as they were teachers at the outset of human evolution: "Microorganisms not only protect us by competing with potentially dangerous organisms, they teach the immune system how to function". ${ }^{67}$ When making the first fermented food product in the book, T'ej (an Ethiopian honey wine), Katz instructs makers to "trust" yeast, a single-celled micro-organism. ${ }^{68}$ T'ej can turn sour with an extended fermentation, but readers should not fear the process: "Microorganisms are flexible and adaptable.... And if you stick with them they will teach you". ${ }^{69}$ Ferments often go wrong, so readers would do well to remember that "we are not, by any measure, in complete control" and that we can "learn from" the unexpected outcomes of microbial interactions. ${ }^{70}$ Katz's books insists that readers be willing to "collaborate" with tiny beings, and in Art Katz foregrounds the pedagogical role of fermenting micro-organisms when he gives the philosopher Lisa Heldke her own page for a short list-essay entitled, "Fermentation Taught Me". One of the many lessons found in Heldke's mini-essay runs, "rules alone cannot teach you how to do something", ${ }^{71}$ 
thus implying that something other than rules-fermenting microbes-must do the teaching. As pedagogues, fermenting micro-organisms lead a form of interspecies counter-conduct predicated on collaboration, trust, a giving up of human-only control and an investment in learning from more-than-rules. Linked to the AIDS virus in Katz and Greenberg's genealogy of interspecies counter-conduct, barely visible fermenting life proves to be another microscopic yet highly active protagonist in a lesser known history of science and medicine.

If Katz's work positions fermenting microbes as instructors giving lessons on how to ferment specific dishes, he also describes them as articulating revisions to forms of human behaviour, chronologies and spaces that exceed the kitchen. Fermenting micro-organisms, for instance, lead humans to surprising forms of care and temporalities that exceed or recede from progressive linearity. Thus, they are properly depicted by Katz as shepherds conducting humans towards modified forms of social behaviour.

To take care of fermenting microbes, for instance, one might revise the act of care so that it includes abandonment. In Wild, Katz writes of making sourdough bread that you must "discard" some of the sourdough culture-a yeast ecosystemeach time you feed it water and flour. With regular attention, meaning regular disposal, a sourdough starter "can live forever". Learning from fermenting microbes, then, humans see nurture is an eternal process but only if you are willing to enact loss on the thing you care for forever. ${ }^{72}$ Time, too, changes in close proximity to the microbial guide. As you wait for ferments to make material change, you see time is not an anthropocentric process that can be merely waited out by fast-moving humans. Shoyu, a soy sauce-like product made with added filamentous fungus called Aspergillus oryzae, can ferment for 3 years before it is ready for consumption in food for humans. How long something like sauerkraut-in its most simple form, sliced cabbage plus salt plus wild lactic acid bacteria-ferments will depend on " $\mathrm{pH}$, water activity, and salinity; the temperature and humidity of the environment; the way [objects] are stored; and [personal] tolerances" ${ }^{73}$ In intimate proximity to different fermenting micro-organisms, time is marked by atmosphere and saltiness while cycles of existence are circular and regenerative. Led by microscopic life converting sugar to alcohol and carbon dioxide, Katz finds interspeciated experiences of care and time that he relays to his human readers. Human behaviour is conducted by barely visible existents that are endowed with authority and guidance. Then, human thinking is altered by those same microorganism's pedagogies. Untraditional experts articulating idiosyncratic care practices and paradigms they may be: fermenting microbes and the AIDS virus are shepherds and protagonists in two related interspecies narratives of care and conduct.

Katz's books do not date from the early years of the AIDS underground and beneficial coexistence with microbial life is no longer such a radical position. By 2017, numerous NIH-backed Human Microbiome Project investigators had published over 650 scientific publications, and the EU plans to spend €498 million on microbiome research by $2020 .{ }^{74}$ 'Good' microbes are now desirable, expensive commodities that can be purchased in health food stores to aid human health, and new research on the enteric immune systems foregrounds, for instance, "interactions among microbiota, enteric neurons, and immune cells for gastrointestinal homeostasis". ${ }^{75}$ As Paxson and Helmreich write, "the abundant microbe has moved from being a sign of peril to being also one of promise". ${ }^{76}$

But the point is not that the early AIDS underground anticipated recent biomedical realisations that desirable microbial communities can be cultivated to improve human health. Rather, the insight is that there exists in the history of AIDS a strain of interspecies care that humans received when they let themselves be led by non-human, pathologised forms of existence rather than biomedical authority. Although beneficial relations with microscopic lifeforms lie at the heart of both recent technoscientific health and DIY fermentation projects, Katz and Greenberg go further by demonstrating what it looks like when human thought and behaviour, not just human health, are altered by a pedagogic relations with micro-organisms and viruses. PWAs developed and continue to develop every manner of relationships with their illness, and this paper has foregrounded one way that two people living with AIDS de-pathologised, indeed exalted, what was and remains a stigmatised disease by turning it and its metonymic agents into sources of empowering knowledge. Katz and Greenberg did not just force the AIDS virus or fermenting bacteria to signify in a new way. ${ }^{77}$ The interspecies counter-conduct that Greenberg and Katz model and describe is a frame for comprehending people who find in microscopic life (especially pathologised microscopic life) a guide towards unconventional forms of care, revised forms of human behaviour and philosophies for persisting with illness.

\section{Contributors JAL planned, wrote and researched this paper.}

Funding The authors have not declared a specific grant for this research from any funding agency in the public, commercial or not-for-profit sectors.

Competing interests None declared.

Patient consent for publication Not required.

Provenance and peer review Not commissioned; externally peer reviewed.

Data availability statement There are no data in this work.

\section{NOTES}

1. Jon Greenberg. "Needle Treatment Pays Off." ACT UP/NY, n.d. R. 26 b. 34 f. 11. ACT UP New York records.

2. Joseph Montanez (2018). "The Task of Undertaking Medical Management of Hispanic Patients." ACT UP/NY, n.d. R. 25 b.33 f. 8. ACT UP New York records.

3. Anna Blume, 2018. "Peptide T: General Information." ACT UP/NY, n.d. B. 33 f. 17. ACT UP New York records.

4. The curatorial team behind the U.S. National Library of Medicine's impressive online exhibition "Surviving and Thriving: AIDS, Politics, and Culture" write in their introduction, "Reactions to the disease, soon named AIDS... were as varied as the uncertainties about it. Early responders cared for the sick, fought homophobia, and promoted new practices to keep people healthy". Other than certain safe sex initiatives, these "new practices" receive hardly any description in the exhibition. See: Jennifer Brier and Emily Easton (2013). NIH: U.S. National Library of Medicine (2013) "Surviving and Thriving: AIDS, Politics, and Culture." September 2013. https://www. nlm.nih.gov/exhibition/survivingandthriving/

5. Emprise, Inc. was hired by the National Institute of Allergy and Infectious Diseases (NIAID) with a US\$47 000 grant on 1 September 1988 to evaluate the "dangers and general worthlessness" of "questionable approaches" to AIDS. According to the report on the grant's financing and language by the AHTC, Emprise's grant application to NIAID included specific examples of how the database might turn a profit after completion, including "sale of online time to families patients at cost... Rent modems to families/patients... Rent videos through commercial agencies..." See: Alternative and Holistic Treatment Subcommittee (1988). "Grace Powers Monaco, Emprise, and the Database on 'Unproven Remedies for AIDS'. " ACT UP/NY, June 1988. R. 25 b.34 f. 3. ACT UP New York records. "Major Questionable (Dubious) Remedies to Prevent or Treat AIDS." NIAIS (1988) R. 25 b.34 f. 3. ACT UP New York records. The Alternative \& Holistic Treatment Subcommittee, and The Insurance and Access Committee, "Stop the Insurance Industry's Blacklist of Unapproved AIDS Treatments," n.d. R. 25 b.34 f. 2. ACT UP New York records. The Alternative \& Holistic Treatments Committee, and The Insurance and Health Care Access Committee (1991). "Re: Participation in a National Action at the 1991 Annual Convention of the American Medical Association, June 22-24, 1991," n.d. R. 25 b.33 f. 1-3. ACT UP New York records.

6. Epstein, Steven. Impure Science: AIDS, Activism, and the Politics of Knowledge. University of California Press, 1996. 23.

7. Ibid, 14.

8. For more on "existents" see Elizabeth A Povinelli (2016). Geontologies: A Requiem to 
Late Liberalism.

9. Julie Livingston and Jasbir Puar (2011). "Interspecies." Social Text 29, no. 1 (Spring): 3-14.

10. Ibid, 7

11. Heather Paxson and Stefan Helmreich (2014). "The Perils and Promises of Microbial Abundance: Novel Natures and Model Ecosystems, from Artisanal Cheese to Alien Seas." Social Studies of Science 44, no. 2: 165-93.

12. The form of interspecies care I am describing resonates with what Maria Puig de la Bellacasa describes in "Making Time for Soil: Technoscientific Futurity and the Pace of Care" and Naisargi N. Dave (2017) describes in "Something, Everything, Nothing; Or, Cows, Dogs, and Maggots". De la Bellacasa foregrounds feminist approaches to care that draw "attention to glimpses of alternative, liveable relationalities, and hopefully contributes to other possible worlds in the making" (692). Meanwhile, Dave writes about interspecies forms of care that emerge in persistent states of precarity and thus occur without enduring "for what is it to endure when there is no future" (45). See: Maria Puig de la Bellacasa (2015). "Making Time for Soil: Technoscientific Futurity and the Pace of Care." Soc Stud Sci Social Studies of Science 45, no. 5 (2015): 691-716; Naisargi N. Dave (2017) "Something, Everything, Nothing; Or, Cows, Dogs, and Maggots." Social Text 35, no. 1 (130) (March 1, 2017): 37-57.

13. Michelle Murphy (2013). Seizing the Means of Reproduction: Entanglements of Feminism, Health, and Technoscience. Durham, N.C.: Duke University Press.

14. Michel Foucault, 2007. Security, Territory, Population. New York: Palgrave Macmillan, 2007. 199.

15. Scholarship on gay men, sexual desire and AIDS has developed nuanced ways of understanding risk, and I take their point that just because something is risky does not mean it is unhealthy or epistemically valueless. Tim Dean (2009) Unlimited Intimacy Reflections on the Subculture of Barebacking. University of Chicago Press, 2009. Halperin, David M. "What Do Gay Men Want?: An Essay on Sex, Risk, and Subjectivity." University of Michigan Press, 2009. Julie Herrada and Tim Retzloff (2009) "Shamefully Gay: Documents from the Labadie Collection." In Gay Shame, edited by David M Halperin and Valerie Traub. Chicago: University of Chicago Press.

16. Jon Greenberg (1993). "Political Funerals." ACT UP NY, 16 July 1993. http://www. actupny.org/diva/polfunsyn.html\#anchor3067986

17. Jon Greenberg and Anna Blume (1991). "Treatment Alternatives: Teach-In." Treatment Alternatives, November 25, 1991. R.24 b.33 f.1-3. ACT UP New York records.

18. Ibid

19. Jon Greenberg (1991). "Treatment Alternatives," September 1991. R. 25 b.33 f. 1-3. ACT UP New York records.

20. Ibid

21. Ibid

22. Ibid

23. Ibid

24. Ibid

25. Jon Greenberg (1992). "Report from West Coast," June 2, 1992. R. 25 b.33 f. 1-3. ACT UP New York records.

26. Jon Greenberg (1992). "Choosing Therapies for Individual Treatment Strategies." Presented at the VIII International Conference on AIDS, Amsterdam, 1992. http://www. actupny.org/treatment/greenbergChoose.html

27. Ibid

28. Ibid

29. Ibid

30. Ibid. Greenberg's rhetoric and his beliefs are strong but not exceptional. Historian Jennifer Brier, in her November 2017 presentation at the American Studies Association, described similar language appearing in the oral histories she conducted with women living with HIV. Because it was the first time that some of these women received meaningful care, became part of a care-based community, or had access to supportive housing and disease treatment, some reported that "HIV saved [their] life." For other uses of HIVIAIDS as "gift" see also Dean, Tim. Unlimited Intimacy: Reflections on the Subculture of Barebacking. Chicago: University of Chicago Press, 2009.

31. Ibid

32. Ibid

33. Epstein, Impure Science, 292

34. Ibid, 293.

35. Foucault, Security, Territory, Population, 199.

36. Ibid, 194

37. Ibid, 127.

38. Ibid, 127

39. Ibid, 194

40. Ibid, 194-195

41. Foucault cycles through the inadequacies of "revolt", "disobedience" and "insubordination" before getting to "dissidence", a term that may be exactly suited to the form of resistance he wishes to convey but which he'd sooner "cut [his] tongue out than use" (200). Dissidence describes the rejection of a system of power that forces obedience to a form of truth and a system of truth — exactly the kind of conduct Foucault wishes to describe - but he cannot accept it for the word has too much "substantification". From dissidence, there is the dissident and then there is an identity ripe for proliferation in discourse and celebration in "hero worship". "Counterconduct", the phrase that Foucault ultimately settles with, satisfactorily conveys resistance to processes implemented to conduct subjects, and the term is preferable because it does not allow for an identity to form around the concept-counterconductor sounds too silly, I suppose.

42. Ibid, 199

43. In a remarkable passage expertly preserved in the English by Graham Burchell's 2007 translation, Foucault writes of the word, 'conduct': "... it is clear that in French we either benefit from or are the victims of... possessing a word whose ambiguity is nonetheless quite interesting... the word, obviously, is 'conduct (conduite)', since the word 'conduct' refers to two things. Conduct is the activity of conducting (conduire), of conduction (la conduction) if you like, but it is equally the way in which one conducts oneself (se conduit), lets oneself be conducted (se laisse conduire), is conducted (est conduit), and finally, in which one behaves (se comporter) as an effect of a form of conduct (une conduite) as the action of conducting or of conduction (conduction)".

44. Foucault, Security, Territory, Population, 202.

45. Michel Foucault (1982). "The Subject and Power." Critical Inquiry Critical Inquiry 8, no. 4: 777-95.

46. Nicole Shukin (2012). "Tense Animals: On Other Species of Pastoral Power." CR: The New Centennial Review 11, no. 2: 146

47. Ibid, 152

48. Ibid.

49. Greenberg, Jon. "Choosing Therapies" (emphasis mine)

50. Ibid,

51. Michael Pollan (2012). "Foreward." In The Art of Fermentation: An in-Depth Exploration of Essential Concepts and Processes from around the World, 14-17. White River Junction, Vt.: Chelsea Green Pub.

52. For more on radical faeries, queer homesteading and popular coverage of Katz see: Peter Hennen (2008) Faeries, Bears, and Leathermen Men in Community Queering the Masculine. Chicago: University of Chicago Press. Burkhard Bilger (2014). "Nature's Spoils." The New Yorker, July 21, 2014.Ann Husaini and Emily Lobsenz (2017). "'Sandorkraut: A Pickle Maker."' The New York Times, December 21, 2017, sec. Opinion.

53. Jon Greenberg and Sandor Katz (1992). "Announcement: Treatment Alternatives Project.". R. 25 b.33 f. 1-3. ACT UP New York records.

54. Sandor Ellix Katz (2003). Wild Fermentation: The Flavor, Nutrition, and Craft of LiveCulture Foods. White River Junction, Vt.: Chelsea Green Pub.

55. For a survey of practices that engage what I call "not-just-human life" see: Justin Linds (2016) "Becoming Microbial." Scapegoat Journal 09 (Winter/Spring 2016): 37-47.

56. Ed Cohen and Julie Livingston (2009) suggests that narrating and analysing AIDS at the scale of the individual and the microscopic lifeform rather than the scale of the epidemic allows us to reject "population thinking", with its focus on global containment and highly scalable regimes of care, in order to stay with the particularities of each confounding virus. By looking at "gradations and relations" involving minute lifeforms, we as people taking disease seriously learn something about the political particularities of life's pathogenic interrelations, human and nonhuman. See: Ed Cohen (2011) "The Paradoxical Politics of Viral Containment; or, How Scale Undoes Us One and All." Social Text 29, no. 1106 (March 20, 2011): 15-35. https://doi.org/10.1215/01642472-1210247

57. Katz, Wild Fermentation

58. Ibid, 4 .

59. Sandor Ellix Katz (2012). The Art of Fermentation: An in-Depth Exploration of Essential Concepts and Processes from around the World. White River Junction, Vt.: Chelsea Green Pub. 195.

60. Ibid, 195.

61. Ibid, 229

62. Sandor Ellix Katz (2006). The Revolution Will Not Be Microwaved: Inside America's Underground Food Movements. White River Junction, Vt.: Chelsea Green Pub. 196

63. Ibid, 197 (emphasis mine)

64. For a foundational historical example in the history of science see: Londa Schiebinge (1993). "Why Mammals Are Called Mammals: Gender Politics in Eighteenth-Century Natural History." The American Historical Review 98, no. 2: 382-411.

65. Andrew Hunt (1999). Dictionary of Chemistry. Routledge. 151

66. Katz, Wild Fermentation, 1,4.

67. Katz, Wild Fermentation, 9. 
68. Ibid, 29

69. Ibid, 28

70. Ibid 30.

71. Lisa Heldke (2012). "Fermentation Taught Me." In The Art of Fermentation: An inDepth Exploration of Essential Concepts and Processes from around the World, 109. White River Junction, Vt.: Chelsea Green Pub.

72. Ibid, 96.

73. Katz, The Art of Fermentation, 56.

74. Dirk Hadrich (2018). "Microbiome Research Is Becoming the Key to Better Understanding Health and Nutrition." Frontiers in Genetics vol. 9 (June 13, 2018).

75. Yuuki Obata and Vassilis Pachnis (2016). "The Effect of Microbiota and the Immune System on the Development and Organization of the Enteric Nervous System." Gastroenterology 151, no. 5 (November 2016): 836-44.

76. Paxson, and Helmreich, "Perils and Promises", 167

77. Paula A. Treichler (1987). "AIDS, Homophobia and Biomedical Discourse: An Epidemic of Signification." Cultural Studies 1, no. 3: 263-305.

\section{BIBLIOGRAPHY}

Alternative and Holistic Treatment Subcommittee. Grace Powers Monaco, Emprise, and the Database on 'Unproven Remedies for AIDS': ACT UP/NY, 1988. R. 25 b.34 f. 3. Act UP New York records.

Bilger, Burkhard. Nature's Spoils: The New Yorker, 2014.

Cohen, Ed, and Julie Livingston. "AIDS." Social Text 27, no. 3 (2009): 39-42.

Cohen, Ed. "The paradoxical politics of viral containment; or, how scale Undoes us one and all." Social Text 29, no. 106 (2011): 15-35.

Dave, Naisargi N.. "Something, Everything, Nothing; Or, Cows, Dogs, and MAggots." Social Text 35, no. 130 (2017): 37-57. no..

Blume, Anna. Peptide T: General Information: ACT UP/NY. n.d. B. 33 f. 17. Act UP New York records.

Brier, Jennifer, and Emily Easton. Surviving and Thriving: AIDS, Politics, and Culture: NIH: U.S.National Library of Medicine, 2013. https://www.nlm.nih.gov/exhibition/ survivingandthriving/

de la Bellacasa, Maria Puig. "Making Time for Soil: Technoscientific Futurity and the Pace of Care." Social Studies of Science 45, no. 5 (2015): 691-716.

Dean, Tim. Unlimited Intimacy: Reflections on the Subculture of Barebacking. Chicago: University of Chicago Press, 2009. http://public.eblib.com/choice/publicfullrecord. aspx? $=448538$

Foucault, Michel. "The Subject and Power." Critical Inquiry 8, no. 4 (1982): 777-95.

—. Security, Territory, Population. New York: Palgrave Macmillan, 2007. York records Needle Treatment Pays Off. ACT UP/NY. n.d. R. 26 b. 34 f. 11. Act UP New

- Treatment Alternatives, 1991. R. 25 b.33 f. 1-3. Act UP New York records.

Greenberg, Jon, and Anna Blume. "Treatment Alternatives: Teach-In." Treatment Alternatives, 1991. R.24 b.33 f.1-3. Act UP New York records.

Greenberg, Jon, and Sandor Katz. Announcement: Treatment Alternatives Project, 1992. R. 25 b.33 f. 1-3. Act UP New York records.

. "Choosing Therapies for Individual Treatment Strategies. Presented at the VIII International Conference on AIDS, Amsterdam.", 1992a. http://www.actupny.org/ treatment/greenbergChoose.html.

Greenberg, Jon. Report from West Coast, 1992b. R. 25 b.33 f. 1-3. Act UP New York records.

"Political Funerals.": ACT UP NY, 1993. http://www.actupny.org/diva/ polfunsyn.html\#anchor3067986
Hadrich, Dirk. "Microbiome Research Is Becoming the Key to Better Understanding Health and Nutrition." Frontiers in Genetics 9 (2018). https://doi.org/

Heldke, Lisa. "Fermentation Taught Me." In The Art of Fermentation: An in-Depth Exploration of Essential Concepts and Processes from around the World, 109. White River Junction, Vt.: Chelsea Green Pub, 2012.

Hennen, Peter. Faeries, Bears, and Leathermen Men in Community Queering the Masculine. Chicago: University of Chicago Press, 2008.

Herrada, Julie, and Tim Retzloff. "Shamefully Gay: Documents from the Labadie Collection." In Gay Shame, edited byDavidM Halperin, and Valerie Traub. Chicago: University of Chicago Press, 2009.

Hunt, Andrew. Dictionary of Chemistry. London, UK: Routledge, 1999. http://ebookcentral. proquest.com/lib/nyulibrary-ebooks/detail.action?doclD=1666754

Husaini, Ann, and Emily Lobsenz, The New York Times. "Sandorkraut: A Pickle Maker.", 2017. https://www.nytimes.com/2015/07/28/opinion/sandorkraut-a-pickle-maker. html.

Wild Fermentation: The Flavor, Nutrition, and Craft of Live-Culture Foods. White River Junction, Vt.: Chelsea Green Pub, 2003.

- The Revolution Will Not Be Microwaved: Inside America's Underground Food Movements. White River Junction, Vt.: Chelsea Green Pub, 2006.

- The Art of Fermentation: An in-Depth Exploration of Essential Concepts and Processes from around the World. White River Junction, Vt.: Chelsea Green Pub, 2012.

Linds, Justin. "Becoming Microbial." Scapegoat Journal 9 (2016): 37-47.

Livingston, Julie, and Jasbir Puar. "Interspecies." Social Text 29, no. 1 (2011): 3-14.

Montanez, Joseph. The Task of Undertaking Medical Management of Hispanic Patients: ACT UP/NY, 2018. n.d. R. 25 b.33 f. 8 Act UP New York records

Murphy, Michelle. Seizing the Means of Reproduction: Entanglements of Feminism, Health, and Technoscience. Durham, NC: Chesham: Duke University Press; Combined Academic, 2013.

NIAIS. Major Questionable (Dubious) Remedies to Prevent or Treat AIDS, 1988. R. 25 b.34 f. 3. Act UP New York records.

$\mathrm{NIH}$ : U.S. National Library of Medicine. "Surviving \& Thriving: AIDS, Politics, and Culture.", 2013. https://www.nlm.nih.gov/exhibition/survivingandthriving/index.html.

Obata, Yuuki, and Vassilis Pachnis. "The Effect of Microbiota and the Immune System on the Development and Organization of the Enteric Nervous System." Gastroenterology 151, no. 5 (2016): 836-44.

Paxson, Heather, and Stefan Helmreich. "The Perils and Promises of Microbial Abundance: Novel Natures and Model Ecosystems, from Artisanal Cheese to Alien Seas." Social Studies of Science 44, no. 2 (2014): 165-93.

Pollan, Michael. "Foreward." The Art of Fermentation: An in-Depth Exploration of Essential Concepts and Processes from around the World, 14-17. White River Junction, Vt.: Chelsea Green Pub, 2012.

Povinelli, Elizabeth A. Geontologies: A Requiem to Late Liberalism, 2016.

Schiebinger, Londa. "Why Mammals Are Called Mammals: Gender Politics in EighteenthCentury Natural History." The American Historical Review 98, no. 2 (1993): 382-411.

Shukin, Nicole. "Tense Animals: On Other Species of Pastoral Power." CR: The New Centennial Review 11, no. 2 (2012): 143-67.

The Alternative \& Holistic Treatment Subcommittee, and The Insurance and Access Committee. Stop the Insurance Industry's Blacklist of Unapproved AIDS Treatments. n.d. R. 25 b.34 f. 2. Act UP New York records.

The Alternative \& Holistic Treatments Committee, and The Insurance and Health Care Access Committee. Re: Participation in a National Action at the 1991 Annual Convention of the American Medical Association, 1991. n.d. R. 25 b.33 f. 1-3. Act UP New York records.

Treichler, Paula A.. "AIDS, Homophobia and Biomedical Discourse: An Epidemic of Signification." Cultural Studies 1, no. 3 (1987): 263-305. 